\title{
33. K-Ar STUDIES OF CHERTS FROM DEEP SEA DRILLING PROJECT SITE 464, NORTHERN HESS RISE ${ }^{1}$
}

\author{
Roger Hart, School of Oceanography, Oregon State University, Corvallis, Oregon
}

\begin{abstract}
$\mathrm{K}-\mathrm{Ar}$ studies of deep-sea cherts are potentially useful for age information and also for information on chert diagenesis and the ${ }^{40} \mathrm{Ar} /{ }^{36} \mathrm{Ar}$ ratio of the paleoatmosphere. Previous studies of Precambrian cherts by Alexander (1976) and Hart (in press) indicated that the argon-isotope record of most cherts has been preserved intact on the larger-than-hand-specimen scale. A relatively good K-Ar isochron with an age of 1890 m.y. has been obtained for the biogenous Gunflint chert (Hart, in press).
\end{abstract}

The K-Ar results for two cherts from DSDP Site 464, on northern Hess Rise, are given in Table 1. Host sediment from Core 10 was paleontologically dated as Late Cretaceous (Doyle and Riedel, this volume), and Core 33 was dated as early Albian to late Aptian (Site 464 report, this volume). Both samples are predominantly quartz, with minor amounts of chalcedony (Hein et al., this volume). Radiogenic argon was not detected in the Late Cretaceous samples, assuming that the ${ }^{40} \mathrm{Ar} /{ }^{36} \mathrm{Ar}$ ratio of the Late Cretaceous ocean was similar to the ratio of the modern-day atmosphere (259.5). On the same assumption, the Albian chert has a K-Ar age of 69 m.y., which is probably 10 to $30 \mathrm{~m}$. y. too young, according to the paleontological information.

There are a number of possible explanations for the deficiency of radiogenic Ar in these samples. First, it seems possible that cherts are not argon-retentive for the first 15 to $40 \mathrm{~m} . \mathrm{y}$. of their history. It has been demonstrated that $\mathrm{K}$ and other large cations are expelled from the lattice during the transformation from opal-CT to quartz (Mizutani, 1977). It is unlikely that argon is held within the lattice during diagenesis.

A second possible explanation for the lack of radiogenic $\mathrm{Ar}$ in deep-sea cherts is preferential diffusion of ${ }^{36} \mathrm{Ar}$ into the chert from the atmosphere during diagenesis. If the diffusion process is slow compared to the process of diagenesis, and if diffusion stops upon the cessation of diagenesis, a non-equilibrium argon-isotope ratio could be preserved by the chert, kinetic preference being given to the lighter isotope.

A third possible explanation for the deficiency of radiogenic $\mathrm{Ar}$ is that the cherts formed in an atmosphere with a ${ }^{40} \mathrm{Ar} /{ }^{36} \mathrm{Ar}$ ratio lower than that of the contemporary atmosphere. This hypothesis is strengthened by the observation that the initial ${ }^{40} \mathrm{Ar} /{ }^{36} \mathrm{Ar}$ ratio of the Albian sample calculated from the $\mathrm{K}$ content and the paleontological age is similar to that of the Late Creta-

\footnotetext{
1 Initial Reports of the Deep Sea Drilling Project, Volume 62.
}

Table 1. K-Ar parameters of Site 464 cherts.

\begin{tabular}{ccccc}
\hline Sample & $\begin{array}{c}40 \mathrm{Ar} \\
\left(10^{-6} \mathrm{~cm}^{3} / \mathrm{g}\right)\end{array}$ & $\begin{array}{c}40 \mathrm{Ar} / 36 \mathrm{Ar} \\
\left(10^{-8} \mathrm{~cm}^{3} / \mathrm{g}\right)\end{array}$ & $\begin{array}{c}\mathrm{K}-\mathrm{Ar} \text { Age } \\
(\mathrm{m} . \mathrm{y} .)\end{array}$ \\
\hline $464-10-4,34 \mathrm{~cm}$ & 6.04 & 290 & 2.08 & 0 \\
$464-33-1,14 \mathrm{~cm}$ & 3.99 & 308 & 1.30 & 69 \\
\hline
\end{tabular}

ceous chert and in the range 287 to 290 . A paleoatmosphere with a ${ }^{40} \mathrm{Ar} /{ }^{36} \mathrm{Ar}$ ratio lower than that of the contemporary atmosphere was hypothesized by Cadogan (1977), who detected a low ratio in gas released at high temperature from the Devonian Rhynie chert.

It is probable that future measurements will shed light on which of the possible explanations for the deficiency of ${ }^{40} \mathrm{Ar}$ is most realistic. For example, if a suite of chert samples of the same age should yield a good $\mathrm{K}-\mathrm{Ar}$ isochron, diffusion as a determining factor could be eliminated, because the enrichment of ${ }^{36} \mathrm{Ar}$ by diffusion would not be proportional to the $\mathrm{K}$ contents. If the isochron age agreed with the paleontological age, it could be concluded that the ${ }^{40} \mathrm{Ar} /{ }^{36} \mathrm{Ar}$ ratio of the paleoatmosphere was different from that today. If the isochron age were significantly younger than the paleontological age, it could be concluded that cherts are not argon-retentive during the first phase of their diagenetic history. A comparative study of two different phases of the same age, such as opal-CT and quartz, would shed light on the effects of diagenesis on argon retention and diffusion. If the quartz-rich chert had a lower ${ }^{40} \mathrm{Ar}$ content than the opal-CT porcellanite, then argon would have been expelled from the lattice during diagenesis. If the quartz sample had a higher ${ }^{36} \mathrm{Ar}$ content than the opal-CT sample, then the argon diffused into chert from the atmosphere during diagenesis.

Until more $\mathrm{K}$-Ar data on Cretaceous cherts are available, it seems worthwhile to compare the chert results with data on other Cretaceous minerals. Deficiency of radiogenic Ar has been reported in Cretaceous glauconites (Hurley, 1966), and in minerals from a Cretaceous pyroxene quartz diorite (Brown et al., 1974). The deficiency of ${ }^{40} \mathrm{Ar}$ in glauconites has been attributed to diffusive loss of ${ }^{40} \mathrm{Ar}$ after formation of the mineral (Evernden et al., 1961). The low ${ }^{40} \mathrm{Ar} /{ }^{36} \mathrm{Ar}$ ratios in the Cretaceous pyroxene quartz diorite have been attributed to a mantle source of $\mathrm{Ar}$ less radiogenic than atmospheric Ar (Brown et al., 1974).

The $\mathrm{K}$ - $\mathrm{Ar}$ data on Cretaceous ${ }^{40} \mathrm{Ar}$-deficient minerals are plotted on a $\mathrm{K}-\mathrm{Ar}$ isochron diagram in Figure 1. In the construction of this diagram, it was assumed that a 
variety of minerals trapped initial argon from an atmosphere of uniform isotopic composition. The data, including those on the DSDP cherts, form a reasonably good linear array, suggesting that diffusive addition of ${ }^{36} \mathrm{Ar}$ was not a dominant process during the history of any of the minerals. The pyroxene quartz diorite minerals alone give a $\mathrm{K}-\mathrm{Ar}$ isochron age of 115 to $122 \mathrm{~m}$.y., with a ${ }^{40} \mathrm{Ar} /{ }^{36} \mathrm{Ar}$ intercept of 275 . The glauconite data give a $\mathrm{K}-\mathrm{Ar}$ isochron age of $91 \mathrm{~m} . \mathrm{y}$. and a ${ }^{40} \mathrm{Ar} /{ }^{36} \mathrm{Ar}$ intercept of 256. The glauconite data combined with the DSDP chert data give a K-Ar isochron age of 90 m.y., with a ${ }^{40} \mathrm{Ar} /{ }^{36} \mathrm{Ar}$ intercept of 268 . The results strongly suggest that the DSDP chert and a variety of other Cretaceous minerals formed in an atmosphere with ${ }^{40} \mathrm{Ar} /$ ${ }^{36} \mathrm{Ar}$ ratio substantially lower than that of the present atmosphere.

It should be pointed out that the age information given here cannot be considered accurate, because the samples used are not necessarily the same age, and because the amount of contamination by modern atmospheric argon is unknown. The results do give promise, under conditions of strict control and removal of atmospheric-argon contamination, that the $\mathrm{K}-\mathrm{Ar}$ iso- chron technique applied to cherts of the same age will yield reliable radiometric ages.

\section{REFERENCES}

Alexander, E. C., Jr., 1976. ${ }^{40} \mathrm{Ar} /{ }^{36} \mathrm{Ar}$ studies of Pre-Cambrian cherts: an unsuccessful attempt to measure the time evolution of the atmospheric ${ }^{40} \mathrm{Ar} /{ }^{36} \mathrm{Ar}$ ratio. Precambrian Res., 2:329.

Brown, J. F., Harper, C. T., and Odom, A. T., 1974. Petrogenetic implications of argon isotopic evolution in the upper mantle. Nature, 250:130,

Cadogan, P. H., 1977. Paleoatmospheric argon in Rhynie Chert. Nature, 268:38.

Evernden, J. F., Curtis, G. H., Obradovich, J., et al., 1961. On the evaluation of glauconite and illite for dating sedimentary rocks by the potassium argon method. Geochim. Cosmochim. Acta, 23:78.

Hart, R. A., in press. Apparent $\mathrm{K}-\mathrm{Ar}$ ages of cherts. Nature.

Hurley, P. M., 1966. K-Ar dating of sediments. In Schaeffer, O. A., and Zahringer, J., (Eds.), Potassium Argon Dating: New York (Springer-Verlag), pp. 205-242.

Hurley, P. M., Cormier, R. F., Hower, J., et al., 1960. Reliability of glauconite for age measurement by $\mathrm{K}-\mathrm{Ar}$ and $\mathrm{Rb}-\mathrm{Sr}$ methods. Bull. Am. Assoc. Petrol. Geol., 44:1793.

Kistler, R. W., and Dodge, P., 1966. Potassium-argon ages of coexisting minerals from pyroxene-bearing granitic rocks in the Sierra Nevada, California. J. Geophys. Res., 71:2157.

Mizutani, S., 1977. Progressive ordering of cristobalitic silica in the early stages of diagenesis. Contr. Mineral. Petrol., 61:129.

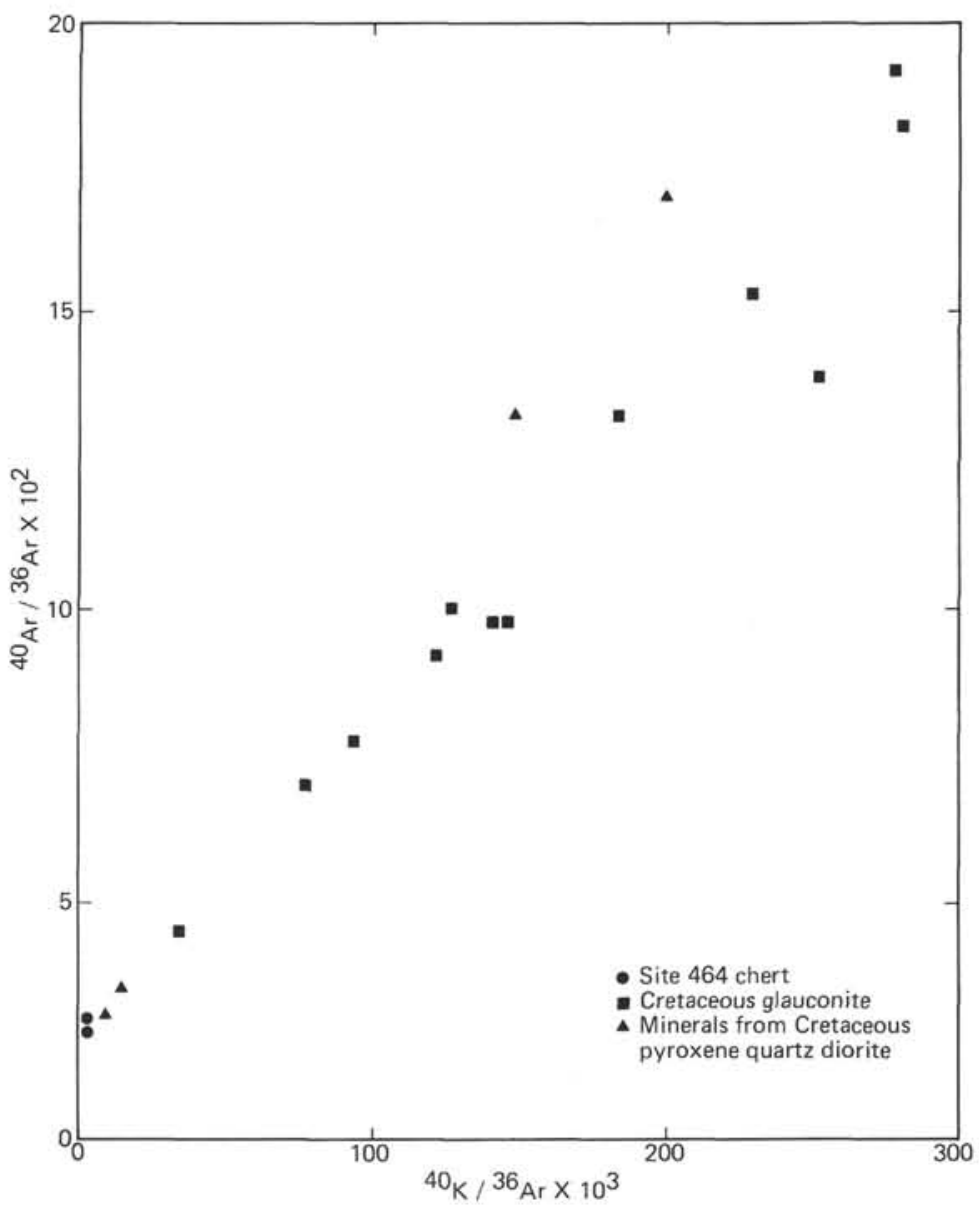

Figure 1. $\mathrm{K}-\mathrm{Ar}$ isochron diagram comparing $\mathrm{K}-\mathrm{Ar}$ data from DSDP Site 464 cherts with data on other Cretaceous ${ }^{40} \mathrm{Ar}$-deficient minerals. See text for results of isochron calculations. Glauconite data from Hurley et al. (1960) and Evernden et al. (1961). Pyroxene quartz diorite data from Kistler and Dodge (1966). 